\title{
Pengaruh Psikoedukasi Mindfulness Singkat pada Kemampuan Regulasi Emosi Mahasiswa
}

\begin{tabular}{l} 
Achaddiana Islamiyah', Mei \\
'Institusi/afiliasi, Negara \\
I,2,3Pusat Pemberdayaan Ke \\
\hline Info Artikel \\
\hline Sejarah Artikel: \\
Diterima \\
I4 Agustus 2019 \\
Direview \\
07 Februari 2020 \\
Disetujui \\
I7 Februari 2020 \\
Dipublikasikan \\
27 Februari 2020 \\
\hline Keywords: \\
Emotional Regulation; \\
Mindfulness; \\
University Student
\end{tabular}

Achaddiana Islamiyah', Mei Sismawati ${ }^{2}$, Dian Veronika Sakti Kaloeti ${ }^{3}$

'Institusi/afiliasi, Negara

${ }^{1,2,3}$ Pusat Pemberdayaan Keluarga, Fakultas Psikologi Universitas Diponegoro, Indonesia

\begin{abstract}
Abstrak
Transisi menuju kehidupan perkuliahan adalah masa yang penuh tekanan. Sehingga diperlukan keterampilan psikologis untuk beradaptasi dengan baik. Salah satunya adalah regulasi emosi. Penelitian ini bertujuan untuk mengetahui pengaruh pemberian psikoedukasi singkat mengenai mindfulness terhadap kemampuan regulasi emosi pada mahasiswa baru Universitas Diponegoro. Sebanyak 5 partisipan yang terdiri dari 2 laki-laki dan 3 perempuan mahasiswa baru dari beberapa fakultas di lingkungan Universitas Diponegoro direkrut dan diberikan edukasi mengenai mindfulness selama I minggu. Penelitian ini menggunakan pendekatan kuantitatif eksperimen dengan desain satu kelompok pretest dan posttest. Penelitian ini menggunakan dua skala untuk mengukur perubahan dalam regulasi emosi dan mindfulness Uji wilcoxon signed rank dan statistik deskriptif digunakan untuk mengevaluasi efek perlakuan yang diberikan. Analisis statistik menunjukkan bahwa tidak ada perbedaan signifikan di antara kemampuan regulasi emoi $(p=0,0025)$ dan kesadaran $(p=0,680)$. Tetapi perbandingan rata-rata menunjukkan adanya sedikit peningkatan. Implikasi dari temuan akan dibahas lebih lanjut dalam artikel ini.
\end{abstract}

\section{The Influence of Brief-Mindfulness Psychoeducation on} Students Emotional Regulation Ability

Transition to university life is a stressful period. Therefore, in order to successfully adapt, there are some psychological skills that need to be developed. One of them is emotional regulation. The aim of this study is to investigate the effect of brief mindfulness psychological education to emotional regulation skill of first-year student of Diponegoro University. This study is a quasi-experiment with one group pretest-posttest design. Five participants included 2 males and 3 females of firstyear student from varieties of faculty at Diponegoro University were recruited and given the psychological education of mindfulness in a week span. Two scale were used to measure the changes in emotional regulation and mindful-state. Wilcoxon signed rank test and statistic descriptive were used to evaluate the effect. The statistical analysis revealed that there was no significant difference in both emotional regulation skills $(p=0,225)$ and mindful-state $(p=0,680)$. But, mean comparison suggested that there were slightly increase. The implication of this findings was discussed.

\footnotetext{
*Alamat korespondensi:

[ll Prof Soedarto, SH, Tembalang, Semarang, Jawa Tengah]

[dvs.kaloeti@live.undip.ac.id]
} 


\section{Pendahuluan}

Transisi ke kehidupan perkuliahan adalah salah satu periode yang penuh tekanan dengan berbagai tuntutan akademik dan sosial (Bewick, Koutsopoulou, Miles, Slaa, \& Barkham, 20I0). Selain itu, sebagian besar mahasiswa tahun pertama mulai hidup sendiri untuk pertama kalinya dan harus mengembangkan regulasi diri agar mampu mengurus dirinya sendiri (Sallis, Owen, \& Fisher, 2008). Para mahasiswa ini tidak hanya dihadapkan dengan stresor utama yang berkaitan dengan hidup mandiri untuk pertama kalinya, tetapi juga tekanan yang signifikan untuk menunjukkan performa yang baik dalam rangka mencapai kesuksesan personal dan profesional dalam kehidupan di periode berikutnya (Beiter dkk., 20I5). Menurut Tinto (dalam Olani, 2009) tahun pertama perkuliahan adalah periode transisi kritis, karena masa tersebut adalah waktunya mahasiswa untuk meletakkan dasar atau pondasi yang selanjutnya akan mempengaruhi keberhasilan akademik.

Bersamaan dengan hal-hal baru yang terdapat di lingkungan perguruan tinggi mahasiswa butuh kesiapan secara psikologis maupun sosial. Mahasiswa dituntut untuk mampu melakukan penyesuaian diri. Penyesuaian adalah proses menemukan dan mengadopsi mode berperilaku yang sesuai dengan lingkungan atau perubahan pada lingkungan (Mangal, 2002). Penyesuaian juga melibatkan proses menghadapi stres, konflik, tekanan, dan pemenuhan kebutuhan (Julia \& Veni, 2012). Penyesuaian diri pada kehidupan universitas terdiri atas penyesuaian akademik, sosial, personal-emosional, dan institusional (Taylor \& Pastor, 2007). Berdasarkan salah satu studi yang mengukur keempat penyesuaian ini, ditemukan bahwa penyesuaian personal-emosional memainkan peran penting dalam menentukan keberhasilan transisi dalam kemampuan akademik (Taylor \& Pastor, 2007).

Memahami sumber daya intrapersonal yang mungkin membantu dalam mempromosikan resiliensi dan melindungi kesejahteraan psikologis selama masa transisi dari kehidupan sekolah menengah ke perguruan tinggi mungkin mampu menyediakan arah yang bermanfaat untuk intervensi berbasis konseling (Kaloeti, Rahmandani, Sakti, Salma, Suparno \& Hanafi, 2019). Salah satu dinamika intrapersonal yang berhubungan dengan tingkat penyesuaian diri, terutama penyesuaian personalemosional, terhadap kehidupan perkuliahan adalah kemampuan regulasi emosi.

Secara luas, regulasi emosi didefinisikan sebagai proses netral untuk memodulasi respons emosional seseorang pada lingkungan, baik yang sifatnya adaptif maupun maladaptif, sebagai respons terhadap emosi positif atau negatif (Aldao, 2013). Praktik regulasi emosi seseorang telah diteliti secara ekstensif dalam literatur tentang cara coping siswa terhadap stresor kampus (Tamir, John, Srivastava, \& Gross, 2007), di mana aspek dari regulasi emosi didemonstrasikan memiliki asosiasi langsung dalam mencegah stres dan memelihara kesejahteraan di berbagai domain (John \& Gross, 2004).

Mengikuti model proses dari Gross (2015), regulasi emosi meliputi tindakan mengubah lingkungan yang memicu emosi (modifikasi situasi), menghadiri dan secara kognitif menilai pengalaman lingkungan, serta secara fleksibel mengalibrasi usaha sebelumnya dalam meregulasi emosi untuk mencapai tujuan yang diinginkan dengan lebih baik. Cara kategoris untuk menginterpretasi lingkungan seseorang akan membentuk pengalaman emosional serta strategi yang akan digunakan dalam meregulasi emosi (Gross \& Barrett, 20II).

Secara lebih spesifik, jenis regulasi emosi yang berhubungan erat dengan keberhasilan adaptasi terhadap lingkungan baru adalah regulasi emosi adaptif. Regulasi emosi yang adaptif merujuk pada kemampuan untuk secara fleksibel merespons pengalaman emosional dengan cara yang berorientasi tujuan dan sesuai dengan tuntutan situasi. Hal ini kemudian akan menuntun pada berkurangnya distress dan promosi afek positif (Gratz \& Roemer, 2004). Kemampuan ini diperlukan karena kehidupan mahasiswa tahun pertama kebanyakan akan dihadapkan pada berbagai situasi baru yang penuh tuntutan sehinggan perlu kemampuan regulasi yang adaptif untuk merespons berbagai pengalaman yang dinilai menyebalkan atau menekan (Finkelstein-Fox, 20I8).

Definisi dari Gratz dan Roemer (2004) mengenai regulasi emosi yang adaptif mirip dengan konsep mindfulness yang mana bertumpu pada tindakan mengenali dan mengakui pemikiran dan perasaan 
yang muncul. Hanya saja, regulasi emosi sebagian besar tersusun atas kemampuan regulasi kognitif dan perilaku serta modulasi respons yang terus menerus. Oleh karena itu, meskipun konsep ini seakan bertumpang tindih dengan mindfulness, dua konsep ini berbeda dalam hal tujuan akhirnya.

Mindfulness melibatkan kesadaran sepenuhnya pada pengalaman yang terjadi di setiap momen yang sengaja dibawa seseorang dengan cara yang lembut, tanpa penghakiman, dan penuh penerimaan (Segal, Williams, \& Teasdale, 2012). Mindfulness adalah kesadaran yang terbuka dan merupakan kondisi perhatian terhadap apa yang terjadi pada saat sekarang (Brown \& Ryan, 2004). Mindfulness didefinisikan sebagai "awareness of present experience, with acceptance" (Germer, 2009). Kondisi mindfulness adalah kondisi individu yang secara sadar membawa pengalamannya ke kondisi saat ini dengan penuh rasa keterbukaan dan rasa penerimaan. Mindfulness membawa kesadaran individu untuk fokus pada tujuan, dengan tidak menghakimi dan tidak menghindari kondisi yang tidak dapat dikuasai (Kabat-Zinn, 2004; Harris, 2009). Menjadi mindful artinya individu sadar akan apapun kondisinya saat ini, terlepas dari kejadian masa lalu dan masa depan (Mace, 2008).

Elemen dalam praktik mindfulness terdapat atensi sadar terhadap perasaan, pemikiran, dan emosi yang terjadi pada momen saat ini, di mana hal ini juga memengaruhi kesehatan mental seseorang. Pengalaman emosional adalah salah satu faktor penting yang menentukan kondisi kesehatan mental seseorang. Ketidakmampuan dan kesulitan untuk memahami, mengekspresikan, dan mengomunikasikan emosi atau lebih parah lagi menekan (suppress) emosi dapat menimbulkan masalah kesehatan fisik maupun mental. Telah dibuktikan melalui berbagai penelitian bahwa menjadi mindful mampu mengantarkan ke kesejahteraan dan kualitas hidup yang lebih baik. Peningkatan kemampuan mindfulness mampu menurunkan kesulitan yang dihadapi saat melakukan regulasi emosi (Rausch, Gramling, \& Auerbuck, 2006).

Kesulitan dalam regulasi emosi telah dibuktikan berhubungan dengan berbagai masalah kesehatan mental, seperti depresi, gangguan kecemasan, gangguan stres paska trauma, dan disfungsi sosial (Gross \& Munov, 1995). Regulasi emosi yang baik berhubungan dengan reorientasi atensi, penilaian kembali yang positif, dan ekspresi emosi. Sementara, disregulasi emosi diasosiasikan dengan ketidakberdayaan yang dipelajar (learned hopelesness), penyalahgunaan narkoba, dan ruminasi (Nelis dkk., 20l I).

Melalui berbagai penelitian, meditasi telah ditemukan mampu membantu membawa kejelasan dalam kondisi emosi, termasuk dalam hal memahami, mengalami, dan meregulasinya. Berdasarkan hasil studi Nielsen \& Kazniak (2006) ditemukan bahwa bahwa meditasi mampu meningkatkan kesadaran dan penerimaan terhadap emosi. Hal ini membuat orang yang mempraktikan meditasi memiliki kemampuan yang lebih baik dalam mendeskripsikan pengalaman emosinya.

Sebagian besar penjelasan mengenai efek mindfulness pada kesejahteraan berhubungan dengan penilaian kognitif dan regulasi atensi dalam merespons pengalaman emosi. Terkait dengan membangkitkan respons kognitif dan emosional terhadap lingkungan seseorang (Gross dkk., 20l l), mindfulness disarankan berhubungan dengan penilaian terhadap stresor eksternal yang secara umum less distressing dan lebih dapat diterima yang pada gilirannya menuntun pada peningkatan pada kondisi afektif (Weinsten, Brown, \& Ryan, 2009). Ketika seseorang memilih untuk sadar dan tidak menghakimi emosinya, hal ini bisa dilihat sebagai bentuk yang efektif dari regulasi emosi karena usaha yang dilakukan untuk mengubah pengalaman. Alih-alih, individu menerima emosi yang sedang dirasakannya (Campbell-Sills dkk., 2006).

Manfaat mindfulness juga mencakup penurunan pada perhatian yang tidak perlu yang didedikasikan terhadap pada pengalaman masa lalu atau masa mendatang serta meningkatkan fokus pada momen yang sedang terjadi di masa sekarang (Desrosiers, Vine, Curtiss, \& Klemanski, 20l4). Melalui promosi keterlibatan tanpa penghakiman terhadap pengalaman saat ini, mindfulness kemungkinan mampu meningkatkan kemampuan mahasiswa untuk berkembang dengan cepat sesuai tuntutan lingkungan. Salah satu penelitian observasional menemukan bahwa disposisi mindfulness diasosiasikan dengan tendensi untuk secara aktif terlibat dengan pengalaman yang sedang terjadi dan menggunakan strategi regulasi yang berfokus masalah (Palmer \& Rodger, 2009). 
Pada penelitian ini, peneliti menggunakan konsep Mindfullness-based Stress Reduction (MBSR) dalam pemberian intervensi (Noonan, 20I4). Terdapat dua komponen utama dalam pelaksanaan proses intervensi mindfulness yaitu atensi terhadap pengalaman saat ini, serta komponen openness (keterbukaan) dan acceptance (penerimaan) terhadap pengalaman diri yang dinilai mampu meningkatkan kesehatan mental dan kondisi emosi individu (Jansse, Heerkens, Kuijer, Heijden, Engels, 20I8). Pada beberapa penelitian, Mindfullness-based Stress Reduction (MBSR) telah dilakukan pada penderita penyakit kronis (Niazi \& Niazi, 20II), penderita kanker (Rush \& Sharma, 20l6), karyawan perusahaan (Jansse, Heerkens, Kuijer, Heijden, Engels, 2018), dan remaja yang menerima bullying (Hidayati, 2019). Namun sejauh ini, peneliti masih sangat jarang menemukan pemberian intervensi ini pada mahasiswa.

Berdasarkan pemaparan di atas, peneliti tertarik untuk mengetahui pengaruh pemberian psikoedukasi mindfulness kepada mahasiswa tahun pertama dalam kemampuan regulasi emosi. Manfaat penelitian diharapkan dapat memperluas kajian ilmu psikologi klinis, psikologi positif khususnya yang berkaitan dengan peran mindfulness pada mahasiswa. Manfaat praktis yang ingin dicapai adalah penelitian ini dapat memberikan informasi bagi mahasiswa dan pemegang kebijakan kampus terkait peran intervensi psikologis dalam membantu meningkatkan keterampilan emosi mahasiswa di kehidupan akademik dan non-akademik.

\section{Metode}

Penelitian ini adalah penelitian eksperimen kuasi dalam rangka mengetahui pengaruh dari pemberian perlakuan Psikoedukasi Mindfulness terhadap Kemampuan Regulasi Emosi pada mahasiswa baru. Desain penelitian yang digunakan adalah one group pretest-posttest. Artinya, hanya ada satu kelompok tanpa kontrol. Perbedaan dilihat dengan membandingkan skor sebelum dan sesudah perlakuan diberikan.

Tabel I.

\section{Rancangan Penelitian}

\begin{tabular}{llll}
\hline Kelompok & Pretest & Perlakuan & Posttest \\
\hline \multirow{2}{*}{ Eksperimen } & YI & $X$ & Y2 \\
& $\mathrm{ZI}$ & & Z2 \\
\hline
\end{tabular}

Keterangan:

YI = Skor mindfulness sebelum psikoedukasi

$\mathrm{ZI}=$ Skor regulasi emosi sebelum psikoedukasi

$X=$ Perlakuan berupa psikoedukasi mindfulness

Y2 = Skor mindfulness sesudah psikoedukasi

Z2 = Skor regulasi emosi sesudah psikoedukasi

Penelitian ini melibatkan lima partisipan yang merupakan mahasiswa semester 2 Universitas

Diponegoro. Teknik pengambilan sampel dilakukan melalui purposive sampling. Kriteria inklusi partisipan yaitu: (I) memiliki skor regulasi emosi dalam kategori rendah; (2) tidak sedang mengikuti program psikoterapi atau konseling; (3) bersedia mengikuti program intervensi yang dibuktikan dengan pengisian informed consent. Penyesuaian personal/emosi diukur dengan menggunakan hasil terjemahan Student Adaptation to College Questionnaire sub-bagian penyesuaian personal/emosi. Secara keseluruhan, proses intervensi melibatkan lima partisipan yang berasal dari Fakultas berbeda.

Skala ini digunakan untuk mengukur tingkat regulasi emosi partisipan. Versi skala ini terdiri atas 18 aitem untuk enam subskala. Difficulties in Emotional Regulation Scale (DERS- I8) Brief Version memiliki reliabilitas internal yang tinggi, baik untuk subskala maupun kesuluruhan skala. Nilai $\alpha$ untuk tiap subskala mulai dari 0,77 (kesadaran) hingga 0,90 (sasaran dan impuls), di mana skor $\alpha$ keseluruhan yaitu 0,91 . 
Five-facet Mindfulness Questionnaire (FFMQ): Short Form digunakanan untuk mengukur tendensi disposisional untuk menjadi mindful dalam keseharian. Skala ini terdiri atas 15 aitem yang menunjukkan korelasi besar dengan skala asli ( $r$ range: $0,85-0,94 ; r_{c}$ range: $0,70-0,85$ ). Sementara itu, nilai alpha untuk tiap subskala bervariasi dari 0,64 sampai dengan 0,83.

Penelitian ini menggunakan desain satu kelompok pretest dan posttest. Adapun prosedur pelaksanaan eksperimen dilakukan dengan pemberian pretest (pada pertemuan pertama), pemberian intervensi sebanyak 3 kali pertemuan dalam satu minggu, serta posttest pada pertemuan terakhir. Pretest dan posttest dalam penelitian ini menggunakan skala yang telah disediakan yaitu Difficulties in Emotional Regulation Scale (DERS) Brief Version dan Five-facet Mindfulness Questionnaire (FFMQ): Short Form. Aktifitas yang diberikan pada pelaksanaan intervensi mengarahkan individu untuk mengoptimalkan komponen - komponen dari mindfulness yaitu berlatih fokus terhadap pengalaman saat ini, openness (terbuka mengenai pengalaman yang dialami), dan acceptance (menerima pengalaman dirinya). Selain itu, peserta diberikan penugasan tiap akhir sesi berlangsung, lebih rinci prosedur eksperimen dipaparkan pada gambar $\mathrm{I}$.

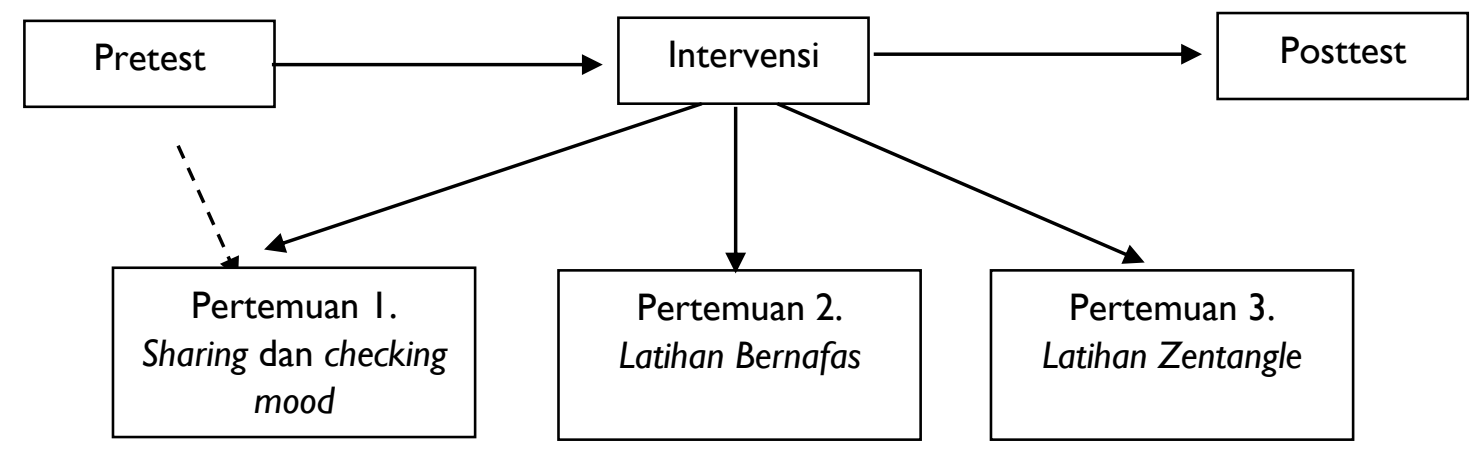

Gambar I. Prosedur Eksperimen

Analisis data dilakukan secara kuantitatif dengan membandingkan skor kesulitan meregulasi emosi dan mindfulness sebelum dan sesudah dan sesudah diberikan pelatihan mindfulness singkat. Perbandingan ini kemudian dianalisis dengan metode statistik uji wilcoxon. Hasil dari uji statistik akan digunakan sebagai dasar inferensi mengenai efektivitas pelatihan mindfulness terhadap regulasi emosi partisipan. Semua analisis statistik digunakan dengan bantuan SPSS versi 24.

\section{Hasil}

Tabel di bawah ini merupakan grafik dan tabel yang mengilustrasikan perubahan kuantitatif sebelum dan sesudah psikoedukasi diberikan.

Tabel 2.

\section{Hasil Uji Wilcoxon}

\begin{tabular}{lcc}
\hline & $\begin{array}{c}\text { Skor Kesulitan Regulasi } \\
\text { Emosi }\end{array}$ & Skor Mindfulness \\
\hline$Z$ & $-1,214^{\mathrm{a}}$ &,$- 412^{\mathrm{a}}$ \\
Asymp. Sig. (2-tailed) &, 225 &, 680 \\
\hline
\end{tabular}

a. Based on negative ranks.

Hasil analisis yang ditampilkan pada tabel 2 menunjukkan bahwa tidak ada perbedaan yang signifikan antara skor sebelum dan sesudah diberi psikoedukasi mindfulness. Hal ini berdasarkan nilai $p$ yang lebih dari nilai taraf nyata $(p>0,05)$, yaitu $p=0,225$ untuk regulasi emosi dan $p=0,680$ untuk mindfulness. Hal ini mengindikasikan bahwa tidak ada pengaruh yang signifikan dari 
pemberian psikoedukasi singkat tentang mindfulness terhadap kemampuan regulasi emosi dan tingkat mindfulness pada partisipan.

Tabel 3 menyajikan perbandingan mean dan standar deviasi untuk setiap skor skala, baik sebelum dan sesudah perlakuan diberikan.

Tabel 3.

Statistik Deskriptif Skor Kedua Skala Pretest-Posttest

\begin{tabular}{llcccc}
\hline & Mean & N & $\begin{array}{c}\text { Std. } \\
\text { Deviation }\end{array}$ & $\begin{array}{c}\text { Std. Error } \\
\text { Mean }\end{array}$ \\
\hline Skala I & $\begin{array}{l}\text { Pretest Kesulitan } \\
\text { Regulasi Emosi }\end{array}$ & 60,80 & 5 & 5,718 & 2,557 \\
& $\begin{array}{l}\text { Posttest Kesulitan } \\
\text { Regulasi Emosi }\end{array}$ & 64,80 & 5 & 10,474 & 4,684 \\
Skala 2 & $\begin{array}{l}\text { Pretest Mindfulness } \\
\text { Posttest Mindfulness }\end{array}$ & 43,00 & 5 & 5,244 & 2,345 \\
& 44,20 & 5 & 3,347 & 1,497 \\
\hline
\end{tabular}

Dari tabel 3, bisa dilihat bahwa ada perubahan mean, baik pada skor regulasi emosi maupun skor mindfulness. Pada skor regulasi emosi yang diukur melalui skala kesulitan regulasi emosi nampak bahwa ada peningakatan nilai mean setelah perlakuan diberikan $\left(M e a n_{\text {pretest }}=60,80, \mathrm{SD}_{\text {pretest }}=5,718\right.$; Mean $\left._{\text {posttest }}=64,80, S D_{\text {posttest }}=10,474\right)$. Hal yang serupa juga terjadi pada skor mindfulness, di mana mean posttest (Mean $=44,20, S D=3,347)$ lebih dari mean pretest $($ Mean $=43,00, S D=5,244)$.

Hasil ini mengindikasikan bahwa adanya perubahan mean pada regulasi emosi yang dialami partisipan, meskipun psikoedukasi mindfulness tidak memberikan pengaruh secara signifikan. Lebih lanjut, perbandingan skor untuk tiap partisipan sebelum dan sesudah diberi perlakuan dapat dilihat pada grafik di bawah ini.

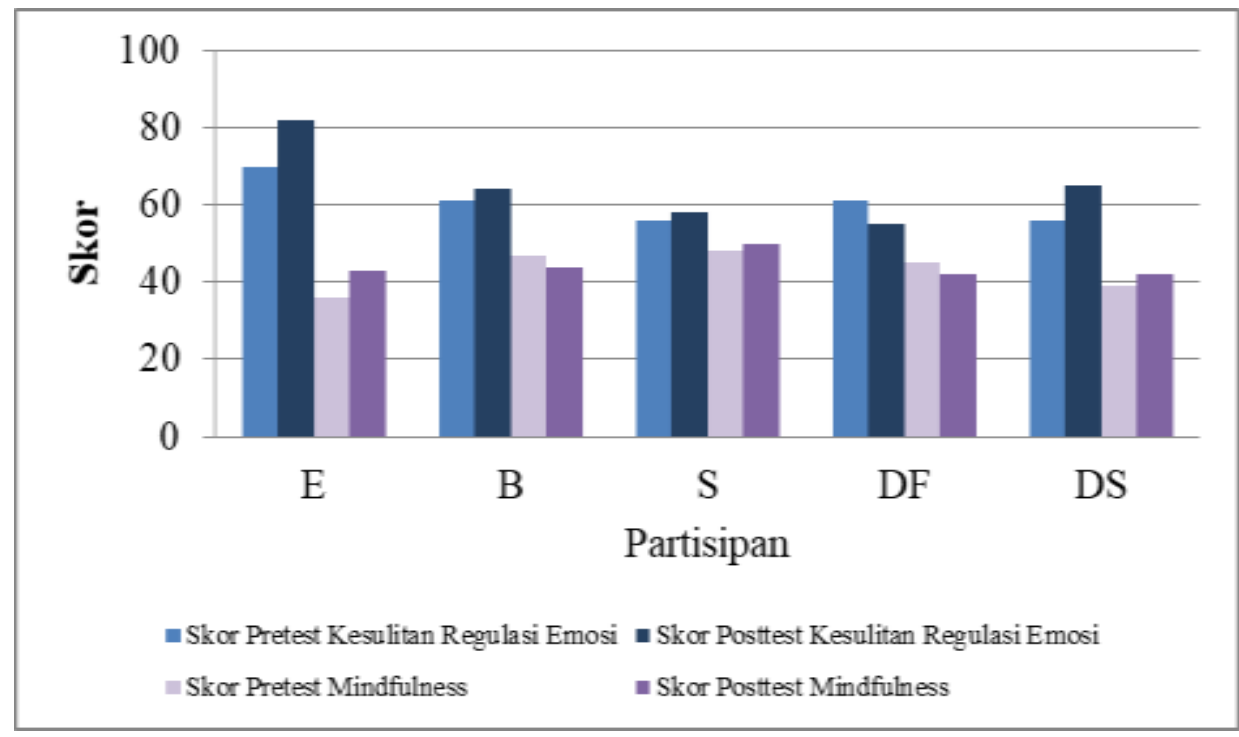

Gambar 2. Perubahan Skor Skala Sebelum-Sesudah Perlakuan

Berdasarkan gambar 2, dapat dilihat bahwa skor untuk kedua skala pada sebagian besar partisipan menunjukkan peningkatan. Hal ini sejalan dengan hasil analisis statistik deskriptif yang telah dipaparkan sebelumnya. Namun, ada beberapa pengecualian, di mana partisipan DF menunjukkan penurunan, baik pada skor regulasi emosi maupun mindfulness. Sementara itu, partisipan B menunjukkan penurunan hanya pada skor mindfulness. Penurunan pada skor mindfulness dapat dijelaskan sebagai pengaruh situasi ketika skala pretest diberikan. Waktu pemberian pretest dilakukan bersamaan dengan periode banyaknya tugas akhir dan tuntutan tugas orientasi kampus 
dari jurusan DF dan B. Patut dicatat bahwa DF dan B berasal dari jurusan yang dikenal memiliki sistem orientasi berat dan penugasan yang sangat banyak.

\section{Pembahasan}

Temuan dalam penelitian ini menunjukkan tidak adanya pengaruh yang signifikan dari pemberian intervensi mindfulness terhadap regulasi emosi partisipan. Sejalan dengan hasil penelitian ini, Shahidi, Akbari, \& Zargar (2017) dalam penelitiannya menemukan bahwa tidak adanya pengaruh yang signifikan pada subskala menyalahkan diri sendiri dalam skala regulasi emosi dari pemberian intervensi mindfulness-based stress reduction (MBSR). Namun menariknya, pada beberapa penelitian lain menunjukkan bahwa mindfulness-based stress reduction secara signifikan dapat menurunkan berbagai permasalahan emosi individu yaitu kecemasan, depresi dan stress (Munazilah \& Hasanat, 2018; Martín-Asuero \& García-Banda, 2010). Fakta tersebut disampaikan pula oleh Chambers, Gullone, \& Allen (2009) bahwa MBSR dapat mengurangi gejala stres, kecemasan, dan depresi, tetapi belum jelas kemampuan spesifik yang dapat ditingkatkan oleh MBSR (Chambers, Gullone, \& Allen, 2009). Disisi lain, regulasi emosi sangat kompleks, mengacu pada berbagai strategi yang bisa diimplementasikan pada situasi yang berbeda-beda yaitu emosi mana yang muncul, kapan dan berapa lama terjadi, dan bagaimana emosi ini dialami dan diungkapkan (Gross, 20II). Sehingga, pemberian perlakuan mindfulness-based stress reduction yang hanya diberikan selama satu minggu dirasa terlalu singkat untuk meningkatkan kemampuan regulasi diri individu.

Salah satu penelitian menunjukkan bahwa manfaat mindfulness dalam bidang akademik baru terlihat setelah siswa mempraktikan aktivitas mindfulness selama rata-rata 90 menit per minggu untuk sekitar 9 minggu (2). Bahkan, salah satu studi yang meneliti tentang efek program mindfulness yang lebih singkat menunjukkan bahwa perubahan yang signifikan baru terlihat setelah minggu keempat. Program intervensi mindfulness dalam format singkat, yaitu empat minggu, mampu membantu mengurangi gejala burnout serta meningkatkan relaksasi dan kepuasan hidup pada sampel perawat (Mackenzie, Poulin, \& Seidman-Carlson, 2006). Pada seting akademik, program mindfulness efektif dalam meningkatkan kemampuan menjadi mindful serta self-compassion (Bergen-Cico, Possemato, \& Cheon, 2013) setelah periode empat minggu. Oleh karena itu, tidak heran jika dalam temuan ini partisipan belum menunjukkan perubahan yang signifikan mengingat program hanya dilakukan dalam satu minggu, di mana pengukuran akhir juga dilakukan di minggu yang sama.

Selain itu, kondisi partisipan dapat menjadi faktor tidak menurunnya permasalahan regulasi emosi yang dirasakan, salah satunya adalah tidak fokusnya individu selama mengikuti intervensi dikarenakan permasalahan kesehatan dan adanya masalah pribadi yang muncul secara tiba-tiba. Menurut Holland, Vries, Hermsen, \& Knippenberg. (20II) individu dapat mengalami perubahan pada moodnya diakibatkan karena adanya masalah yang muncul diantaranya hubungan pertemanan, permasalahan ekonomi, keluarga, dan lain sebagainya. Hal ini dapat menyebabkan individu kurang fokus untuk mengikuti program intervensi.

\section{Kesimpulan}

Berdasarkan hasil analisis penelitian, dapat ditarik sebuah kesimpulan bahwa intervensi yang dilakukan tidak ada perubahan yang signifikan pada regulasi emosi setelah diberikan psikoedukasi dan tidak ada perubahan yang signifikan mengenai kemampuan mindfulness kepada Mahasiswa Baru Universitas Diponegoro. Terdapat beberapa faktor yang mengakibatkan hasil tidak signifikan, salah satunya pada pertemuan yang singkat sehingga kurang efektif. Selain itu, terdapat faktor lain yaitu kondisi partisipan, materi dan metode yang digunakan.

Saran untuk penelitian selanjutnya adalah peneliti harus mempertimbangkan kembali mengenai waktu, metode, dan materi yang digunakan untuk melakukan intervensi yang dilaksanakan. Selain itu, ada baiknya melakukan follow-up paska intervensi selesai. Follow up penting dilakukan untuk 
melihat seberapa jauh efek pelatihan terhadap individu. Pada studi selanjutnya, akan lebih baik jika menggunakan lebih banyak sampel dan melibatkan penggunaan kelompok kontrol.

\section{REFERENSI}

Baker, R. W., \& Siryk, B. (1989). Student adaptation to college questionnaire: Manual. Western Psychological Services.

Brown, K. W., \& Ryan, R. M. (2003). The benefits of being present: Mindfulness and its role in psychological wellbeing. Journal of Personality and Social Psychology, 84, 822- 848.

Chambers, R., Gullone, E., \& Allen, N. B. (2009). Mindful emotion regulation: An integrative review. Clinical Psychology Review, 29, 560 - 572.

Campbell-Sills, L., Barlow, D.H., Brown, T.A., \& Hofman, S.G. (2006). Acceptability and suppression of negative emotion in anxiety and mood disorders. Emotion, 6, 587-595.

Chodron, P. (200I). The places that scare you: A guide to fearlessness in difficult times. Boston, MA: Shambhala Publications.

Feldman, G., Greeson, J., \& Senville, J. (2010). Differential effects of mindful breathing, progressive muscle relaxation, and loving-kindness meditation on decentering and negative reactions to repetitive thoughts. Behaviour research and therapy, 48(10), 1002-1011. doi:10.1016/j.brat.2010.06.006

Germer, C.K., Siegel, R.D., \& Fulton, P.R. (2005). Mindfulness and psychotherapy. Guilford Press, Nueva York.

Gratz, K. L., \& Roemer, L. (2004). Multidimensional assessment of emotion regulation and dysregulation: Development, factor structure, and initial validation of the difficulties in emotion regulation scale. Journal of Psychopathology and Behavioral Assessment, 26, 4I-54.

Gross, J.J., \& Munov, R.F. (1995). Emotion regulation and mental health. Clinical Psychology: Science and Practice, 39, 28I-29I.

Gross, J. J., \& Barrett, L. F. (20II). Emotion generation and emotion regulation: One or two depends on your point of view. Emotion Review, 3, 8-16.

Hidayati, N. (2019). Mindfulness based stress reduction (MBSR) untuk resiliensi remaja yang mengalami bullying. Proceeding Nasional Conference Psikologi UMG 20I8, I(I), 40-49

Holland, R. W., Vries, M. de, Hermsen, B., \& Knippenberg, A. van. (20II). Mood and the attitudebehavior link. Social Psychological and Personality Science, 3(3), 356364. doi:10.1 I77/19485506/1421635

Janssen, M., Heerkens, Y., Kuijer, W., van der Heijden, B., \& Engels, J. (2018). Effects of mindfulness-based stress reduction on employees' mental health: a systematic review. PLOS ONE, I3(I), e019/332. doi:10.137//journal.pone.0191332

Julia, M., \& Veni., B. (20I2). An analysis of the factors affecting student's adjustment at an university in Zimbabwe. International Education Studies, 5(6), 244-25I.

Kabat-Zinn, J. (2003). Mindfulnes-based Interventions in Context: Past, Present, and Future. Clinical Psychology: Science and Practice, 10, I44-I56.

Kaloeti, D. V. S., Rahmandani, A., Sakti, H., Salma, S., Suparno, S. \& Hanafi, S. (2019). Effect of childhood adversity experiences, psychological distress, and resilience on depressive symptoms among Indonesian university students. International Journal of Adolescence and Youth, 24 (2), I77-I84, https://doi.org/I0.1080/02673843.2018.I485584 
Martín-Asuero, A., \& García-Banda, G. (2010). The mindfulness-based stress reduction program (mbsr) reduces stress-related psychological distress in healthcare professionals. The Spanish Journal of Psychology, 13(02), 897-905. doi:10.1017/s I 13874I600002547

Mangal S.K., (2002). Advanced educational psychology. New Delhi: PHI Learning Pvt. Ltd.

Munazilah, M \& Hasanat, N. (20/8). Program mindfulness based stress reduction untuk menurunkan kecemasan pada individu dengan penyakit jantung koroner. Gadjah Mada Journal Of Professional Psychology, 4(I)

Niazi, A.K. \& Niazi, S. K. (20II). Mindfulness-based stress reduction: a non-pharmacological approach for chronic illnesses. Journal Medicine Science, 3(I), 20-30

Nielsen, L., \& Kazniak, A.W. (2006). Awareness of subtle emotional feelings: A comparison of long-term meditators and nonmeditators. Emotion, 6, 392-405.

Noonan, S. (20I4). Mindfulness-based stress reduction. Can Vet Journal, 55(2), I34-I 35.

Taylor, M.A., \& Pastor, D.A. (2007). A confirmatory factor analysis of the student adaptation to college questionnaire. Educational and psychological measurement, 67(6), 1002-1018.

Rush, S. E., \& Sharma, M. (2016). Mindfulness-based stress reduction as a stress management intervention for cancer care. Journal of Evidence-Based Complementary \& Alternative Medicine, 22(2), 348-360. doi:10.1 177/2I565872/666/467

Shahidi, S., Akbari, H., \& Zargar, F. (2017). Effectiveness of mindfulness-based stress reduction on emotion regulation and test anxiety in female high school students. Journal of Education and Health Promotion, 6(87)

Segal, Z. V., Williams, J. M. G., \& Teasdale, J. D. (2002). Mindfulness-based cognitive therapy for depression: A new approach to preventing relapse. New York: Guilford Press.

Sharma, J., \& Singh, A.P. (2016). A studi on mindfulness, regulation of emotion, and mental wellbeing among young adults. IRJMST, 7(9). 